\title{
Application of Value Management by Real Estate Development Practitioners: A Review of Enticing Factors
}

\author{
Yeptadian Sari ${ }^{1}$ and Lutfi Prayogi ${ }^{2}$ \\ ${ }^{1}$ Department of Architecture, Universitas Muhammadiyah Jakarta, \\ Indonesia \\ ${ }^{2}$ Department of Architecture, Universitas Muhammadiyah Jakarta, \\ Indonesia \\ yeptadian.sari@ftumj.ac.id
}

\begin{abstract}
The application of a method in real estate development is needed to ensure the project runs smoothly. Some methods can increase the value of the project and even discard the unnecessary cost of the project called value management (VM). This research is an exploratory research which has applied an inferential statistics. This research has used exploratory factor analysis. Factor analysis is used to discover the benefits of VM practices that are correlated between each indicator, which makes real estate development practitioners interested to apply VM. The sample taking and respondent determination are applied by a purposive sampling followed by snowball sampling. Data collection techniques use a survey by distributing the questionnaires. There are five benefits that can make practitioners interested in applying VM, the benefits are to identified objectives, needs, and project constraints; VM can produce the best designs; VM is capable of deciding on the best project completion; VM facilitating interaction between designers; VM is the method to get the cost-effectiveness of real estate development.
\end{abstract}

(C) 2018 IJBESR. All rights reserved.

Keywords: factors, value management,VM benefits

\section{Introduction}

Value management is a service that maximizes the functional value of a project by managing its progress from concept to completion and commissioning through the audit of all decisions on the value system determined by the client or the owner or the decision-maker of the project and the product [1]. Value management is based on scientific methods of collecting data from reliable sources and on functional requirements [2]. Functional requirements try to meet customer needs and want. Multidisciplinary teams approach to avoid the wrong decision of an individual [3, 4]. Then, it is possible to increase the value of a product by increasing its functionality even if this can make the cost larger, as long as the function increases higher than the additional cost [5].

[6] stated that in value management, decisionmaking could be improved by using a team approach. Everyone has an opinion about what thing that can affects the value of a product.
Often, decisions are made by one dominant person, who base choices on only one criterion, such as cost, quality, or reliability [5]. The decisions made by one dominant person will not be better than the decision determined by the team. A decision that improves quality but increases costs to the point where the product is no longer valuable and becomes unacceptable as one way of reducing costs at the expense of quality or performance required. It is important to avoid confusion between cost and value. If the additional cost does not improve the quality or ability to perform the function needed, then the value decreases. The three essential elements provide a measure of value to the user: functionality, quality, and cost [5, 7].

Value management is viewed as a process involving multiple disciplines and teamwork efforts, hence, negotiation becomes an important role in the value-based decisionmaking process of a component, or building element or system and a support system is required for negotiation in value-based decisions on the value management process [6]. 
The larger and complex a construction project is developed, then the more it involves the various parties who exchange ideas, desires, and concepts through design collaborations [8].

[9] explained that participating groups in the value-management process might be valuemanagement facilitators, project managers, architects, landscape architects, civil engineers, cost estimators, facility operators, operations, and housing workers. It is quite same with [2] that explaining in more detail that the value chain participant may be a value management facilitator, client representative or critical stakeholder of the project, project manager, architect, structural engineer, service engineer, quantity surveyor, construction adviser, contractor principal, specialist contractor, value management facilitator.

There are three phases of value management, namely the orientation and diagnostic phase, the workshop phase, and the last is the implementation phase [5], which consists of 8 stages starting from pre-study information to the construction stage $[5,10]$ Value management uses creative problem-solving techniques, to evaluate critical project decisions strictly. The scales of value management are applied to real estate development ranging from briefing to construction $[4,11]$.

\section{Material and Methods}

This is exploratory research applying inferential statistics using exploratory factor analysis. Factor analysis is used to discover the benefits of VM practices that are correlated between each indicator, which makes real estate development practitioners interested to apply VM. The sample taking and respondent determination are employed by a purposive sampling followed by snowball sampling. Data collection techniques use a survey by distributing the questionnaires, there are thirtyfive samples, namely real estate developers, and they are being or has served as a manager or above. The range of work to examine the value management is quite extensive, it could be from the engineers to the director, but the range of perception of engineers and directors are so far, so as to minimize the perception range, the researchers chose the manager to managing director as the respondent to represent the population. It is also due to the manager and above who know about all stages of the real estate development process. The data that is used in this study consisted of primary data.

\subsection{Value Management Indicators in Real Estate Development Process}

The interest and application of value management by practitioners is shaped by knowledge and willingness, as stated by [5] adapted from Value for Europe: Training and Certification System Manual that awareness arises when having knowledge or information about it. Then it is sought to know in advance the knowledge about the benefits of the implementation of value management in the development of real estate so as to make the practitioners real estate developers are aware or interested and apply value management on the development of their real estate. The benefits of value management are seen starting from the early stages of real estate development, such as the briefing phase that applies the value management process to its construction. So the variable for this research is the variable of the benefit of using value management.

Some of the benefits of value management are, addressing the complexity of the design, facilitating the integration of participants in the design process, producing the best designs, and coordinating the design process mentioned by [8], raising right image and aesthetics [12], improving communication and teamwork, as well as shared understanding among critical participants [2], is a benefit generated by the application of collaborative designs that are one application of the value management method.

Increased project schedule, the benefits of value management mentioned [13] are also mentioned by [14] as the optimization of the project schedule, the benefit of applying value management that can improve the quality of service or product (in this study is real estate) and the quality of its construction.

The benefits of value management that cannot be far from the client's expectation are cost efficiency, whether material cost, plan and design cost [13], capital cost, operational cost and maintenance $[14,15]$, eliminating unnecessary costs [2]. [12] also mentioned that the reduction of environmental pollution as one of the benefits of value management, as well as [14] which states in the explanation of environmental stewardship, and then [15] also indicates it by describing the minimization of adverse environmental impacts.

The extent of flexibility in project implementation from the early stages of the project is also mentioned as one of the benefits of applying value management $[12,15]$. Safety is also one of the benefits of using value management, both the safety of facilities and the environment or the safety, security and health of the construction [12, 14]. Later on, [2] state that value management can improve innovation in the project, as well as [15] stating that value management improves project functionality, improves project usability and convenience, improves project effectiveness, to optimize project value. 
Value management can also be a hindrance to risk and uncertainty [14], and [15] also examined the issue and mentioned that value management is effective in managing risk. Value management can understand the client's wishes, or in this research is the developer.

It can be said that indicators of value management benefits that enticing practitioners of real estate development apply value management shown in Table 1.

Table 1: Indicators of value management benefits

\begin{tabular}{|c|c|c|}
\hline No & Indicators & Source \\
\hline 1 & Minimize change order & $\begin{array}{l}\text { Discussion } \\
\text { with doctor } \\
\text { of real estate }\end{array}$ \\
\hline 2 & Understand the client's wishes & [15] \\
\hline 3 & Functional achievements & {$[2,15]$} \\
\hline 4 & Operational cost efficiency & {$[14,15]$} \\
\hline 5 & Efficient projects & [15] \\
\hline 6 & $\begin{array}{l}\text { Maintain the security of facilities } \\
\text { and personnel }\end{array}$ & {$[12,14]$} \\
\hline 7 & Environmental protection & {$[12,14,15]$} \\
\hline 8 & Optimal project duration & {$[13,14,15]$} \\
\hline 9 & Risk management & {$[14,15]$} \\
\hline 10 & $\begin{array}{l}\text { Maintain the health and safety of } \\
\text { construction }\end{array}$ & {$[12,14]$} \\
\hline 11 & Optimize construction quality & {$[13,14,15]$} \\
\hline 12 & Optimizing cost of capital & {$[14,15]$} \\
\hline 13 & Avoiding project cost swelling & {$[15]$} \\
\hline 14 & $\begin{array}{c}\text { Analysis of design and building } \\
\text { values }\end{array}$ & {$[5]$} \\
\hline 15 & $\begin{array}{l}\text { Minimization of construction cost } \\
\text { swelling. }\end{array}$ & {$[12,15]$} \\
\hline 16 & The best solution in the project & {$[8,12]$} \\
\hline 17 & Best design achievement & {$[8]$} \\
\hline 18 & Coordinate the design process & {$[2,8]$} \\
\hline 19 & $\begin{array}{c}\text { Overcoming the complexity of the } \\
\text { design }\end{array}$ & {$[8]$} \\
\hline 20 & $\begin{array}{c}\text { Assist the integration process } \\
\text { between designers }\end{array}$ & {$[2,8]$} \\
\hline
\end{tabular}

\subsection{Practitioners of Real Estate Development}

At the beginning of the survey stage, it was determined four respondents based on purposive sampling technique; they were four respondents who entered in the study population. From the four respondents, they recommend other respondents that still in part of the population scope and the limits of the study. Thus the technique of determining the sample continues to be a snowball sampling technique from purposive sampling technique. So it takes recommendations of respondents from some previous respondents.

From that survey, it was obtained thirtyfive respondents in accordance with the scope of population and the limitations of this study. So the numbers of samples used in this study are as many as thirty-five people; they are practitioners who are or have served as top managers on the development of the real estate. Of the thirty-five people, nine respondents were project managers, nine respondents were general managers, ten respondents were directors, and seven respondents were part of managers on their real estate development projects.

\section{Results and Discussions}

There were 20 indicators, which were proceeded by inferential statistics using exploratory factor analysis then it was analyzed by SPSS (The Statistical Package for Social Science), and the first step in factor analysis is to measure sample adequacy by comparing the amount of correlation coefficient observed with the partial correlation coefficient.

The next step was to look partially, whether it was feasible or not for indicators to be analyzed and not excluded in testing. Of the 20 indicators, there were 2 indicators that have a value below 0.5 , which means that it was not feasible and it would be excluded from the set of indicators that would be analyzed, they were indicator 'VM is able to maintain the health and safety of construction' and indicator 'VM can maintain the security of facilities and personnel'. Although both concepts are indicated by [12] and [14] indicators that had a loading factor below 0.5 should be discarded.

The next stage was the measurement that determined the number of groups and determined what indicators that could make the practitioner interested in applying the value management. It generated six groups of indicators to be analyzed into a VM factor that makes the practitioners interested to apply the VM on their real estate development that shown in Table 2. 
Table 2. Factors of value management benefits

\begin{tabular}{|cl|}
\hline $\begin{array}{c}\text { Group } \\
\text { number }\end{array}$ & \multicolumn{1}{c|}{ Group of Indicators } \\
\hline 1 & 1) VM can optimize the duration of project \\
construction
\end{tabular}

Value management can understand developer desires [15]. Objectives, needs, and ways to avoid and eliminate constraints in the project are some definitions of the developer's wishes [2]. In defining it, preventing and removing project constraints is one of the things to be considered, commonly called risk management, which usually identifies possible adverse project possibilities, such as changes in project focus, project design changes, changes that occur in project environments such as material that must be replaced suddenly, government regulations on land used for projects and the like. To identify this can be done by brainstorming in the early stages of the value management process, then analyzing the constraints and response of these constraints or risks to explore the possibility of avoiding those risks [5]. As mentioned by [8] that building designs evolved to involve the complexity of engineering systems, where the design process required a variety of participant disciplines to solve complex problems. It is also intended to facilitate the achievement of high building functions $[2,15]$.
Optimizing the duration of project construction, preventing risks and uncertainties in project construction, realizing the developer's desire, achieving high building functionality and overcompensated design complexities are some of the things that can be achieved if the objectives, needs, and project constraints are well identified and responded to. Therefore, such a set of indicators can see the benefits of implementing value management as identified objectives, needs, and project constraints.

In the process of value management, there are stages in which to obtain information in-depth with the objective of knowing the goals, needs and project constraints [2], as well as the identification of high-value and unnecessary items [12] it is possible to know the low quality of design and building by identifying the problems of design and building quality on the real estate development project, and the final stage of the value management process can produce the best design by choosing a design proposal based on the merger analysis of cost criteria (Life Cycle Cost ) and Multi-Criteria Decision Making, and can achieve design with the most optimum investment cost or capital cost [12].

The occurrence of a change order is mainly due to design changes during the execution of the contract. As explained by [8] that collaborative designs are developed with the ultimate goal of producing the best designs. If the best design has been achieved, tailored to the needs and objectives of the project based on multidisciplinary agreement, it can minimize the change of design in the next stage of real estate development, thus minimizing the change order.

The best design can also reduce the adverse impacts of the project environment and surrounding projects; this can be applied if there is one such option in terms of the objectives and needs of the project or be indirect impacts of the implementation of the goals and project needs to be based on the best design achieved.

Thus, such a set of indicators can see the value of applying value management that can produce the best designs. The value management process begins by identifying the function, then analyzing the function by generating alternatives, followed by responding to other options, and the last one deciding or choosing the best option [5]. Optimizing the quality of construction is intended to determine or select the most optimal product, service, and project execution process. In deciding or choosing these alternatives, there are several things to consider, such as needs, forms, and costs. The consideration was able to produce a design agreement and the project implementation 
process. This indicator group can see the value of applying value management capable of deciding on the best project completion.

Value management has a process whereby it involves multi-discipline, collaboration, and teamwork [9]. In the process, multidisciplinarians are facilitated to express their own needs and goals in a project. Starting from the information stage up to the recommendation phase requires communication between project actors [16] to find design decisions. Decisionmaking is at the core of all design activities, starting from defining stages by determining developer/client needs, and setting limits, targets, and at alternative stages by exploring designs and choosing concepts.

This process helps facilitate communication and integration between designers and is able to coordinate the design process through interaction with the actors. This means value management becomes an approach that can improve communication from the common understanding between team members in the project [9]. Therefore, such a group of indicators can see the value of applying value management as facilitating interaction between designers.

In the process of value management, there is an evaluation stage that aims to select alternatives that arise from the stage of creativity [10,12]. At the evaluation stage, the best option is chosen by taking into account the cost criteria or so-called Life Cycle Cost [5] which means the technique to evaluate economically by calculating all relevant costs during the investment period through adjustment time value of money. The selection of these cost criteria is intended to make the overall cost of the calculation effective [2]. The operational cost of property management is included in the relevant costs here.

After the evaluation and development phase has been completed, the recommendation stage is to recommend the outcomes of selected design alternatives, which are based on careful accounting of project specifications, needs and costs through multi-disciplinary recommendations and approvals, one of the objectives are to avoid cost swelling [15]. Thus, such a group of indicators can see the value of applying value management that is the costeffectiveness of real estate development.

\section{Conclusion}

Five benefits can make practitioners interested in applying VM; the benefits are to identified objectives, needs, and project constraints; VM can produce the best designs; VM capable of deciding on the best project completion; VM facilitating interaction between designers; costeffectiveness of real estate development.

\section{References}

[1] Kelly, J. dan Male, S. Value Managent in Design and Construction : The Economic Management of Project, (E. \& F. N Spon, London, 1993).

[2] Connaughton, J. N. dan Green, S.D. Value Management In Construction: A Client's Guide (Construction Industry and Research Information Association, Westminster, 1996).

[3] Wang, L. dkk. Journal of Computer-Aided Design. Collaborative Conceptual Design - State of The Art And Future Trends 34, 981-996. (2002)

[4] Kalay,Y.E., Khemlani, L. \& Choi, J.W.. An Integrated Model to Support Distributed Collaborative Design of Buildings, Automation in Construction Vol. 7, 177-188. (1998)

[5] Kelly, J., Male, S. dan Graham, D. Value Managent of Construction Project (E. \& F. N Spon, London, 2004)

[6] Utomo, C. dan Idrus, A. Journal of Sustainable Development. Vol. 4. A Concept toward Negotiation Support for Value Management on Sustainable Construction, 6 (2011)

[7] Kaufman, J. J. Value Management: Creating Competitive Advantage (Financial World Publishing, Canterbury, Kent, UK, 2001)

[8] Rahmawati, Y et al. An Empirical Model for Successful Collaborative Design Towards Sustainability of Project Development. Journal of Sustainable Development, vol 7, 1 (2014).

[9] Utomo, C. et a 1. A Conceptual Model of Agreement Options for Value-based Group Decision on Value Management. Jurnal Teknologi. 70:7. 39-45 (2014).

[10] Leeuw, C. P. Value Management: An Optimum Solution.International Conference on Spatial Information for Sustainable Development. CMTS2.2 (2001).

[11] Yu, A.T.W dan Shen, Q. Application of Value Management In Project Briefing, Property Management \& Built Environment. Vol. 23 Iss: 7/8. $330-342$ (2005).

[12] Dell'Isola, A. Value Engineering in the Construction Industry (Van Nostrand Reinhold, New York, 1995).

[13] Kubal, M.T., Engineered Quality in Construction (McGraw-Hill, NewYork, NY, 1994).

[14] Cha, H.S., Selecting Value Management Processes For Implementation On Capital Facility Projects (publish dissertation of Phylosophy, The University of Texas at Austin, 2003).

[15] Bowen, P.A. et al. International Journal of Project Management, Elsevier. Value Management Awareness and Practice by South African Architects Construction Innovation (2009).

[16] Leung, M.Y., Ng, S.T. dan Cheung, S.O., Improving satisfaction through conflict stimulation and resolution in value management. Journal of Management in Engineering.18 (2), 68-75. (2002) 
International Journal of Built Environment and Scientific Research Volume 03 Number 01| June2018 p-issn: 2581-1347 | e-issn: 2580-2607 | Pg 15 - 20

(This page is intentionally left blank) 